\title{
FALBA VÉSETT EMLÉKEK \\ Egy 16. századi síremléktípus példái Erdélyből
}

\author{
Mérai Dóra ${ }^{1}$ \\ Magyar Régészet 10. évf. (2021), 1. szám, pp. 41-48. https://doi.org/10.36245/mr.2021.1.3
}

A 16. századi Erdélyben az elhunytakat általában a templomok padozatában vagy a templomok körül fekvö, illetve újonnan létesitett köztemetökben kialakitott sírokba temették. Nem minden sírra került azonban köböl faragott emlék. Valószínüleg fából is készitettek sírjeleket, de ezekröl nem rendelkezünk egykorú forrásokkal. A temetökböl sírkövek eresszel vagy anélkül kialakitva, illetve koporsó alakú kövek maradtak fenn, például a kolozsvári Házsongárdról vagy Marosvásárhelyröl, amelyek feliratokkal, illetve egyszerü faragott ábrázolásokkal örizték meg az elhunytak emlékét. Egy Marosújváron nemrégiben felfedezett felirat esetében azonban a templom külsö támpillérének egy faragott kövét használták fel a sírfelirat elhelyezésére. A feliratos kö egy, a kora újkori Erdélyben jellemzö sirremléktipust képvisel, amelynek legtöbb példája Kolozsvárról ismert. A tanulmány ezeket a síremlékeket tekinti át: pontosan hol, kik és miért választották a megemlékezésnek ezt a formáját.

Kulcsszavak: Erdély, síremlék, sírfelirat, templom, temető, emlékezet, faragvány, kora újkor, 16. század

Egy feliratos kőről készült fotó jelent meg 2020 áprilisában a Műemlékek Fóruma nevü Facebook csoportban, amely az erdélyi Fehér megyében, Marosújváron készült, és élénk érdeklődést váltott ki a fórum tagjai körében (1. kép). ${ }^{2}$ A középkori templom szentélyének egyik támpillérébe falazva, a pillér lépcsőzetes beugrását fedve vízvetőként szolgált. Az épület ma tető nélküli rom, kívül-belül ólakkal és a környező házak egyéb melléképületeivel körbeépítve. ${ }^{3}$ A kő simára faragott, $70 \times 40 \mathrm{~cm}$-es felületén az alábbi szöveg olvasható latinul: HIC IACET MICHAEL SALI | OBYT A(NNO) D(OMINI) 1586 - „Itt nyugszik Sali Mihály, meghalt az Úr 1586. évében.”

Hasonló módon a Szilágy megyei Magyarzsomboron is a szentély délkeleti külső támpillérének egyik kövére véstek rá egy sírfeliratot, itt magyar nyelven: IT FEKSIK SZILAGI | IACAB KIT AZ VRIS | TEN CHODALATOS | KEPPEN KIVOT AZ | VILAGBOL | 1585 (2. kép). Használaton kívül került ez a temp-

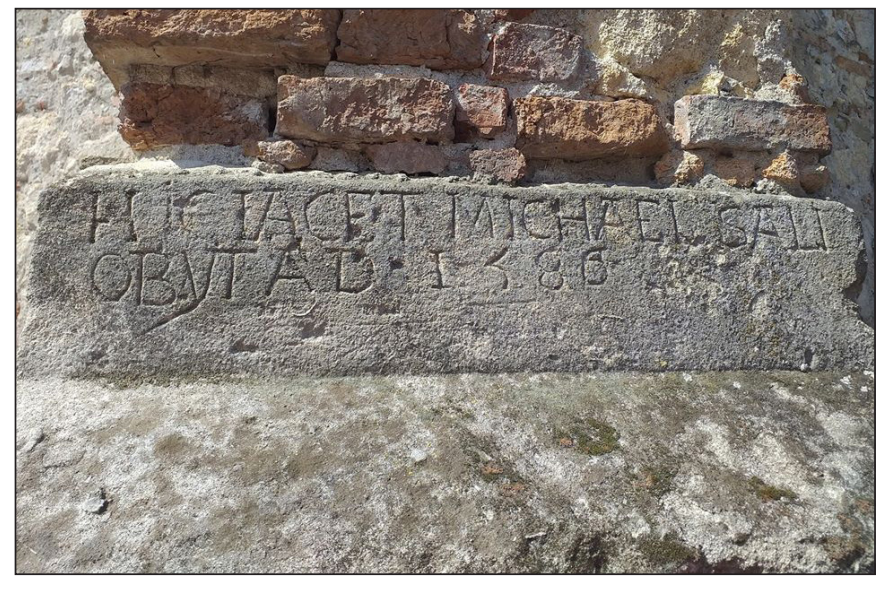

1. kép. Sali Mihály sirremléke, Marosújvár (fotó: Jakab Zsolt Sándor)

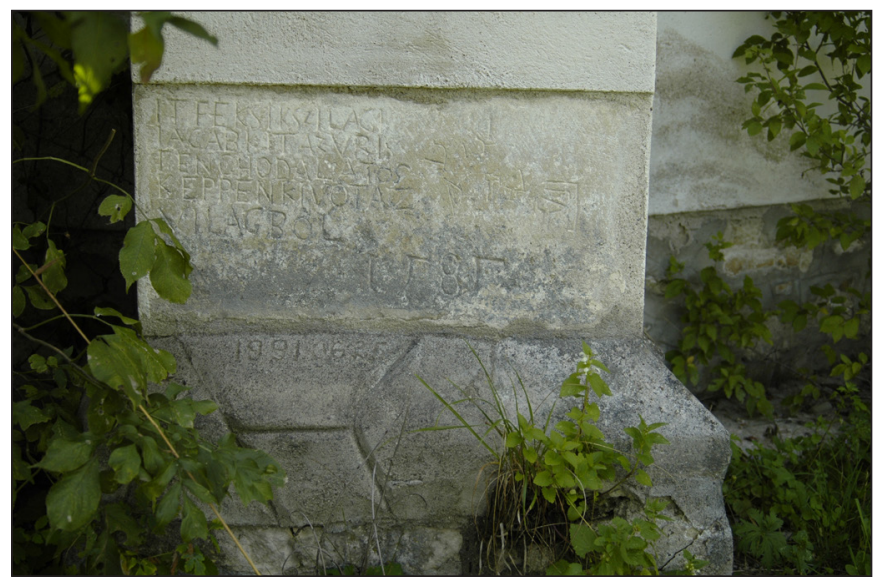

2. kép. Szilágyi Jakab síremléke, Magyarzsombor (fotó: Mérai Dóra)

Közép-Európai Egyetem, Középkortudomány Tanszék, Kulturális Örökség Tanulmányok Program. E-mail: MeraiD@ceu.edu

A Jakab Zsolt Sándor és Kiss Sándor által készített felvételeket Jakab Zsolt Sándor tette közzé. Mindkettőjüknek köszönöm, hogy engedélyükkel felhasználhatom a képeket.

Mai állapotát mutatják a Diaszpóra Alapítvány weboldalán található képek. (Letöltés: 2021. február 2.) 
lom is, elhagyottan áll, bár még valamivel jobb állapotban, mint a marosújvári rom (IsTVÁNFI 2001, 261). Az elnagyoltan bevésett, szabálytalan felirat nem árul el semmi egyebet Szilágyi Jakabról halálának idején és különös körülményein túl. Mellette azonban különféle szerszámok vésett körvonalai jelennek meg, amelyek utalhatnak esetleg a foglalkozására: egy kalapács, egy vonalzó és talán egy ásó, egy véső és egy lapát. A kő felidézheti Jakab építőmester alakját, akivel valami különös baleset történhetett, neve azonban fennmarad, amíg csak végleg össze nem omlik a templom fala, bár ez a kép tényleg nem több a fantázia szüleményénél. A több évszázados, szükszavú síremlékek nemcsak megőrizték az egykor elhunytak emlékét, hanem mint az emlékezet médiumai más, új képeket, akár új emlékeket is inspirálnak (ERLL 2011). Ilyen szempontból nincs különbség egy gazdagon faragott síremlék és egy, a magyarzsomborihoz hasonló, elnagyolt feliratos kő között.

\section{FALBA VÉSETT SÍREMLÉKEK}

A gyakorlat, hogy egy, már álló, akár több évszázados épület falának egyik kövét választják ki, és annak sima felületébe vésik a sírfeliratot, nem a kora újkorban jelent meg. Lővei Pál több példát is összegyüjtött itáliai és német területekről a 13. századtól a 16. század második feléig terjedő időszakból. A középkori Magyarországról is talált 13. századi példát: Martinus Lapicida sírfelirata Kalocsán maradt fenn (LőVEI 2009, 193-195, 414-415, 726-728. kép). Jászapátiban a templom kerítőfala belső oldalának faragott kövein olvashatók hasonló feliratok, amelyek arról tanúskodnak, hogy a szokás a 18. században is élt még (LővEI 2009, 736-737. kép).

A kora újkori Erdélyből a legnagyobb számban Kolozsvárott maradtak fenn hasonló sírfeliratok, amelyeket egy korábban épített fal köveibe véstek. Itt azonban nem templomfalról, hanem a várost védő falvonulatról van szó; az emlékekhez tartozó sírok nem templom körüli temetőben, hanem a város első köztemetöjében helyezkedtek el. A feliratokat elsőként Nagyajtai Kovács István gyüjtötte össze az 1840-es években az angol orvos és utazó, John Paget javaslatára (NAGYAJTAI KovÁcs 1840; 1843). A fal mellett fekvő telkeket még a 18. század végén kiárusították, és, mivel a fal akadályozta a város terjeszkedését, egyre több helyen megkezdték annak elbontását. Mind a bécsi udvar, mind a városi

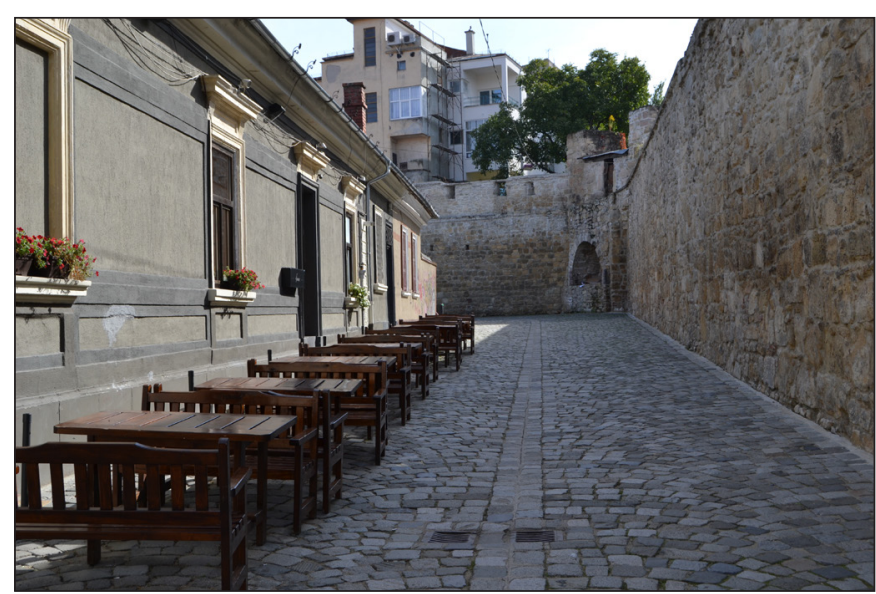

3. kép. A kolozsvári városfal (fotó: Mérai Dóra) tanács elrendelte ugyan, hogy a feliratos köveket meg kell őrizni, de ez a gyakorlatban nem igazán valósult meg (KeRny 2002, 71; Mihály 2013, 19). Nagyajtai Kovács arra a következtetésre jutott, hogy nem a fal építésekor használtak fel korábbi síremlékeket, hanem magának a falnak a faragott építőköveit alakították síremlékekké a felvésett feliratokkal. Feltételezését megerősítette, hogy a közeli építési munkálatok során nagy mennyiségü emberi csontmaradványt látott a földből előkerülni. A kettős városfal két vonulata közti terület valóban temetőként szolgált a kora újkorban. A falak még a 15. század elején épültek, a 16-17. században pedig megerősítették őket egy második vonulattal a keleti, déli és nyugati szakaszokon (3. kép). A források tanúsága szerint az így kialakult falszoros bizonyos részeit alakították temetővé az 1570-es években (MihÁLy 2013, 126).

\section{A TEMETKEZÉS HELYE}

Kolozsvárott, ahogy más városokban Európa szerte, a középkor óta a plébániahálózathoz és a különféle szerzetesrendekhez, ispotályokhoz tartozó templomokat, illetve azok kertjeit használták temetőhelyként (Herepei 1988, 19, 34; Flóra 2014, 289-292; Balogh 1985, 75, 189; Szabó T. 1995, 228). A 16. század közepére azonban megteltek mindezek a temetők, és a városra ezekben az évtizedekben újra meg újra 
Mérai Dóra •Falba vésett emlékek. Egy 16. századi siremléktípus példái Erdélyböl

lesújtó pestisjárvány csak súlyosbította a helyzetet. Ebben az időszakban - az 1540-es évekre - érte el a várost a reformáció, és a szerzeteseket elüldözték. A városvezetés próbált megoldást találni a temetőproblémára, és 1564-ben azzal a kéréssel fordultak a fejedelemhez, hogy a volt ferences kolostor kertjét köztemetővé alakíthassák. Ez azonban nem oldotta meg hosszú távon a helyzetet, így 1573-ban a városfal két vonulata közti területet jelölték ki temetkezés céljára. A szük helyen nem a sírokra állítottak sírköveket, hanem a városfal faragott köveibe vésték bele a sírfeliratokat. Mivel ez a terület is hamar megtelt, a városi tanács már 1586-ban megtiltotta az ide temetkezést, és a városfalakon kívül, a város déli oldalán jelölték ki az új köztemetőt, a mai Házsongárdi temető elődjét (BALOGH 1985, 196; HerePEI 1988, 20).

Európa-szerte ez volt az az időszak, amikor a középkori szokással szakítva a temetkezés tere elkezdett elszakadni a templom terétől és környezetétől, és a temetők lassanként a települések szélére kerültek át. A jelenség részben a protestáns teológiából következett, részben maga is erősítette az ezzel kapcsolatos, vallási alapú véleményeket. Luther maga is amellett érvelt, hogy mivel az élők imádsága nem segíti az elhunytak lelkét a túlvilágon, felesleges és egészségügyi okokból veszélyes is a települések központjában, a templom mellett elföldelni a halottakat. A radikálisabb protestáns irányzatok pedig egyenesen tiltották a templomokhoz kapcsolódó temetkezést mint pápista szokást (OEXLE 1983, 70; KosLOFSKY 2000, 46-77; MÉRAI 2012-2013). Nem kizárólag a protestánsok szorgalmazták azonban ezt a változást. A fejedelem 1579-ben átadta a kolozsvári egykori ferences kolostort a jezsuita rendnek, akik közegészségügyi megfontolásból szintén problémásnak találták a szük kolostorudvarban kialakított temető használatát, és a templomépületben való temetkezést is csak kivételes esetekben engedélyezték (BALOGH 1985, 117). ${ }^{4}$

Az Erdélyi Fejedelemségben a 16. század közepe tájától nemcsak Kolozsvárott, hanem több más városban is a falakon kívül jelöltek ki köztemetőt. Szebenben 1554-ben lépett a tanács ez ügyben a pestisjárványok okozta egészségügyi veszélyre és a templom körüli temetők telítettségére hivatkozva (Rотн 2006, 71, 88). Brassóban viszont csak 1788-ban, a központi uralkodói rendelet hatására zárták le a város temploma körüli temetőt, és alakítottak ki lutheránus köztemetőt a városkapu közelében (GROSs 1925; KüHLBRANDT 1927). A református Marosvásárhelyen 1616-ban alapított köztemetőt a tanács a város északkeleti szélén, amelyet azonban hamarosan átvett az egyház (KELEMEN 1977, 185).

\section{SÍREMLÉKEK A KOLOZSVÁRI VÁROSFALBAN}

A kolozsvári városfal két vonulata közti köztemető kialakítása egy különösen minimalista síremlékformát hozott létre. Mivel a helyhiány miatt nem tudták a sírokra állítani a sírköveket, a fal egy-egy kváderkövét alakították síremlékké a felület megfaragásával és felirattal, amely általában mindössze az elhunytak nevét és egy évszámot tüntet fel. A kiválasztott kövek 60 cm-től 2 m magasságig helyezkedtek el, és a fal tövében folytatott egykori munkálatok során előkerült csontmaradványok alapján úgy tünik, a sírhely mellett vagy felett (Nagyajtai Kovács 1840, 69-71; Nagyajtai Kovács 1843; Deák 1879, 358). Bár Marosújváron és Magyarzsomborban nem ástak le a templomfal közelében, feltételezhetjük, hogy a sírok hasonlóan a feliratos kövek alatt helyezkedhettek el.

Kolozsvárott összesen kilenc hasonló emlék maradt fenn, amelyek közül három Erdély Nemzeti Történelmi Múzeuma kőtárába került azon falszakaszokból, amelyeket az idők során elbontottak (4-6. kép). Egy további követ a Házsongárdi temetőbe helyeztek át, az iktári Bethlen család kriptájának homlokzatába építve (7. kép). Öt, síremlékké alakított kváderkő pedig továbbra is a városfalban, eredeti helyén található (8-9. kép). ${ }^{5}$ A köveket két módon alakították ki: vagy a feliratos mezőt vésték be és alakították simára a felszínét, vagy a feliratos tábla körül faragták vissza a kváderkő felületét. Utóbbi esetekben két sema-

4 Az élők és holtak térbeli elkülönítésének folyamata nem ért véget a 16. században. Az 1770-es, 1780-as évekre több európai államban, így a Habsburg Birodalomban is központilag szabályozták a kérdést: a templom körüli temetkezést már a katolikus uralkodó tiltotta be a felvilágosult abszolutizmus rendszerében. II. József 1784-ben rendelte el az összes, a településeken belül fekvő temető lezárását és külső temetők létesítését (OEXLE 1983, 72-75).

5 A 8. képen Pákei Lajos rajzain látható köveket, illetve Lukács, nemes Szőlősi Lukács deák fia (1574) síremlékét nem tudtam személyesen felmérni, mivel ma elzárt területen találhatók. LöWY et al. (1996, 46-48) és JAKAB (2012, 33-34) közölt fotókat a kövekröl. 
tikus füllel tabula ansata formára egészítették ki a simára faragott mezőt (4., 5. és 7. kép). A feliratok betütípusa minden esetben reneszánsz kapitális, de a minősége széles skálán mozog a kőfaragó ismereteitől függően.

A legtöbb sírfelirat a temető 1573 -as létesítését követő évböl, 1574-böl maradt fenn. Egy darab azonban az 1554-es évszámot viseli, azaz eszerint közel húsz évvel az előtt készült volna, hogy hivatalosan megnyitották a temetőt (4. kép). Ez már csak az elhunyt személye miatt is problémás, aki a felirat szerint Keretszegi János ötvös özvegye. Az ötvösmester 1557-ben még életben volt, így felesége nem lehetett három évvel korábban özvegy (FLÓRA 2014, 379). A felirat magyar nyelve is arra utal, hogy 1570-nél nem nagyon készülhetett korábban, mivel 1574-ből származik a legkorábbi erdélyi

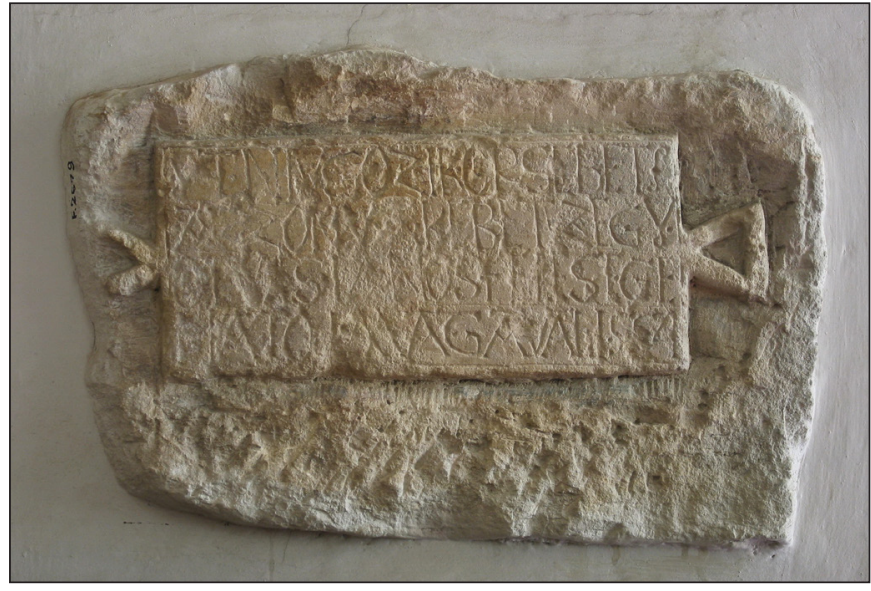

4. kép. Keretszegi Eötves János felesége, Erzsébet, és öt családtagjuk síremléke. Kolozsvár, Erdély Nemzeti Történeti Múzeuma (fotó: Mihály Melinda (C) ENTM). Felirata: YT NIVGOZIK EORSEBET | AZZONY KERETZEGY | EOTVES IANOS FELESEGE | HATOd MAGAVAL 1554 magyar nyelvü sírfelirat éppen innen, a falszorosban kialakított temetőből. ${ }^{6}$ A kő kialakítása és a felirat betüinek stílusa sem mutat akkora eltérést a többi hasonló darabtól, hogy közel húsz év különbséget sejtetne. Mindez arra enged következtetni, hogy az 1554-es évszámot valószínűleg a véső tévedése eredményezte, és ez a kő is 1574-ben készült.

Mivel a falak közti terület hamar megtelt a sírokkal, a városi tanács már 1586-ban le is zárta a temetőt. Úgy tünik, ezt követően már csak kivételesen létesítettek újabb sírokat itt, ha egyáltalán. ${ }^{7}$ A legkésőbbi évszámos kő 1607-böl származik, de csak feltételesen kapcsolható a helyszínhez, mivel másodlagos helyzetből került elő (6. kép). Nagyajtai Kovács István említett további feliratokat is, de hangsúlyozta, hogy ezek hitelességét nem volt alkalma ellenőrizni. Az ő nyomán rögzült az irodalomban, hogy 42 feliratos kőröl van tudomásunk (JAKAB 1988, 224-225; MiнÁLY 2013, 126).

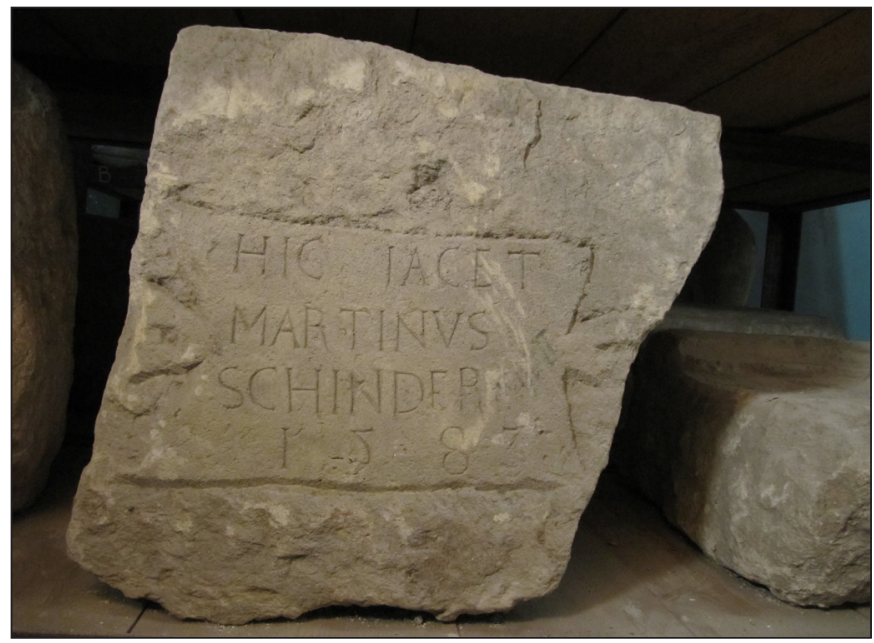

5. kép. Martinus Schinder siremléke. Kolozsvár, Erdély Nemzeti Történeti Múzeuma (fotó: Mihály Melinda (C) ENTM). Felirata: HIC IACET | MARTINVS SCHINDER | 1583

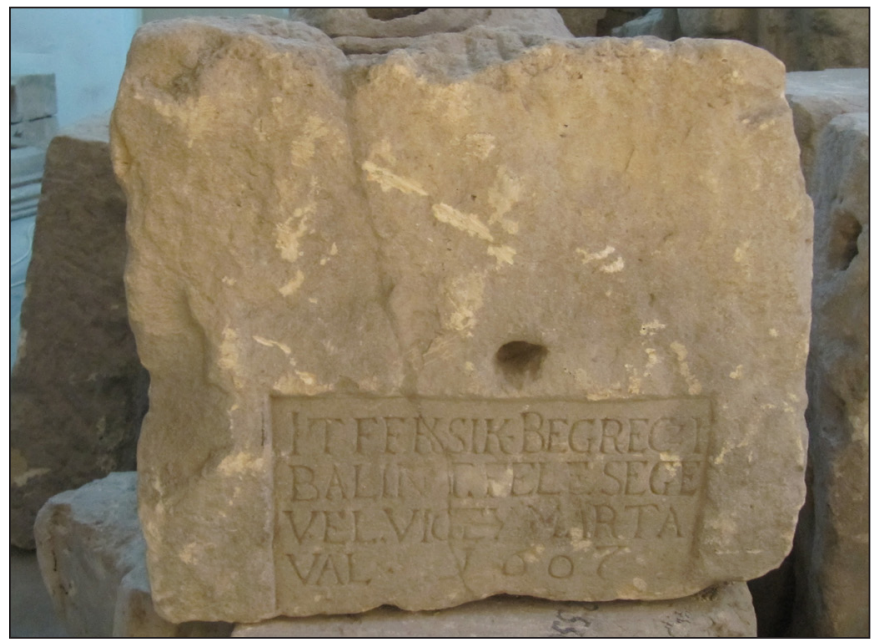

6. kép. Begreczi Bálint és felesége, Viczey Márta sirremléke. Kolozsvár, Erdély Nemzeti Történeti Múzeuma (fotó: Mihály Melinda (C ENTM). Felirata: IT FEKSIK BEGRECZI| BALINT FELESEGE | VEL VICEY MARTA | VAL 1607

6 Az egyetlen magyar nyelvü felirat Erdélyben, amely ezt megelőzően készült, az ebesfalvi kastélyból származik, és egy címerkövön olvasható (BALOGH 1985, 245).

A 19. században Bölöni Farkas Sándor három, Kolozsvárott 1594-ben kivégzett nemes sírfeliratát is látta a falon, akiket a várárokba temettek volna (KERNY 2002, 71, 11. jegyzet). Herepei János szerint a magisztrátus 1602-ben újranyitotta a temetőt (HEREPEI 1988, 24). 
Mérai Dóra • Falba vésett emlékek. Egy 16. századi síremléktípus példái Erdélyböl

\section{KIKNEK AZ EMLÉKÉT ŐRZIK A KOLOZSVÁRI VÁROSFAL KÖVEI?}

Literatus Szőlősi Lukács a felirat szerint nemesember volt, és az előneve - literatus - alapján komolyabb müveltséggel is rendelkezhetett. Szintén Lukács nevü fia emlékére latin nyelvü epitáfiumvers került a városfal egyik kváderkövére. ${ }^{8}$ Ez egy kivételesen gazdag felirat, és valószínüleg az apa iskolázottságának, foglalkozásának tudható be, mivel a többi fennmaradt felirat mindössze egy rövid ,itt nyugszik" formulát tartalmaz. Egy másik literatus, Gergely emlékezetét is őrizte egy kő, amely mára elveszett (Nagyajtai Kovács 1840). Szőlősi Lukács sírversén kívül még egy latin nyelvü felirat maradt fenn, Martinus Schinder emlékére, akiröl csak annyit tudni, hogy 1583-ban hunyt el (5. kép).

A legnagyobb számban ötvösmesterek, illetve családtagjaik jelennek meg a sírfeliratokban. Az említett Keretszegi János, akinek özvegye hatod-

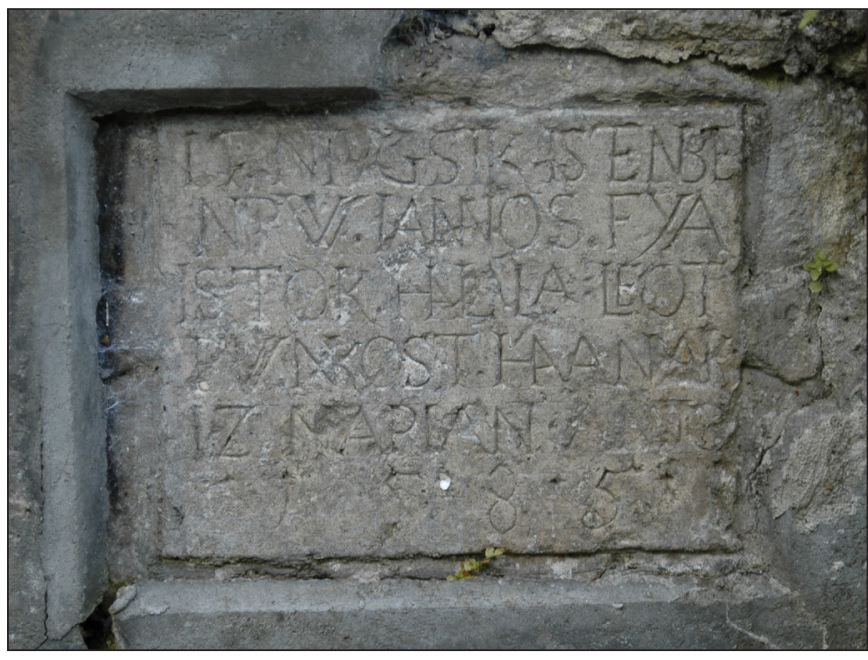

7. kép. Nyírő János fia, Istók síremléke (fotó: Mérai Dóra). Kolozsvár, Házsongárdi temetö. Felirata: IT NIVGSIK ISTENBE | NIRW IANNOS FYA | ISTOK HALALA LEOT | PWNKOST HAVANAK | 12 NAPIAN ANNO | 1585 magával nyugodott az emléktábla alatti sírban, ötvösmester volt és városi diszpenzátor (FlóRA 2014, 379) (4. kép). Begreczi (vagy Pegreczi) Bálint szintén ötvösmester volt, 1600-ban céhmesterként említik, 1605-ben pedig a városi tanács tagja (BALOGH 1985, 195-196). Feleségével, Vicey Mártával közös síremléke a legkésőbbi a városfalból származó hasonló feliratok közül, 1607-es évszámmal (6. kép). A Vicey vagy Wiczey család is jelentős ötvöscsalád volt, amely számos tagot adott a városvezetés számára. Istók, akinek feliratos köve a Házsongárdi temetőbe került, Nyírö János fia volt (7. kép). Egy Nyírő János nevü ötvös 1621-ben és 1622-ben volt a városi tanács tagja, és fennmaradt a vagyonáról a halála után készített leltár (BALOGH 1985, 158; FLóRA 2014, 412). Bányai Ötvös János neve is arra enged következtetni, hogy az ötvöscéh mestere volt, csakúgy, mint Választó Gergely, akinek leányát, Borbálát örökítette meg vésett felirat a városfalban ( $8 b$ és c kép). Választó Gergely neve is közvetlenül a foglalkozására utal, az arany finomításának folyamatára. 1577-ben említik a források mint a kolozsvári ötvöscéh azon tagját, aki a szebeni céhhel való vitában képviselte a város érdekeit. Borbála szintén ötvöshöz, Ötvös Antalhoz ment feleségül (DEÁK 1886, 3).

Számos, a feliratokban megjelenő vezetéknév foglalkozásnévböl ered, mint például Ötvös, Választó, Íjgyártó, vagy akár Tölcséres Pécsi János. Nem egyértelmủ azonban, hogy a hasonló nevek valóban az adott személy foglalkozását jelezték-e. A 16. század utolsó negyedétől kezdtek rögzülni a hasonló vezetéknevek.
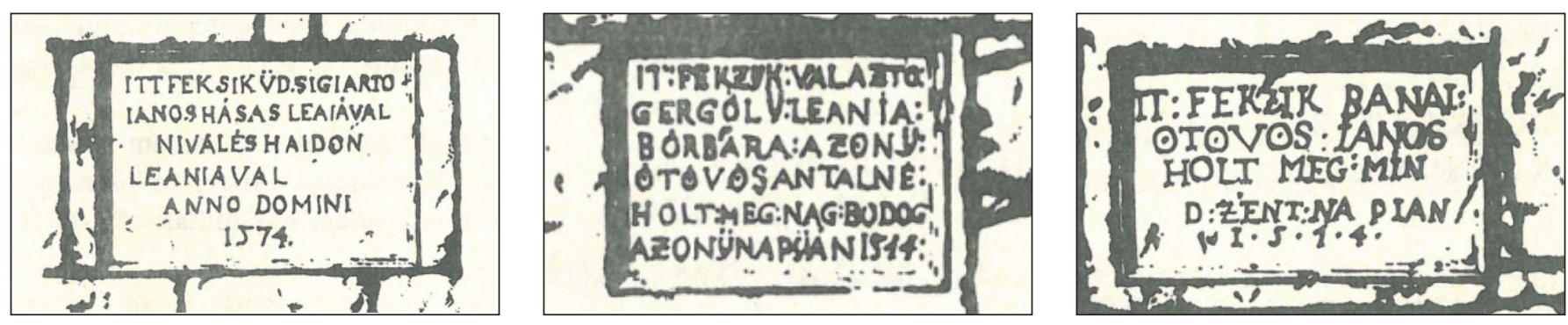

8. kép. Síremlékek a kolozsvári városfalból (Balogh 1944, 186, 5a-b, 6a). a) Íjgyártó János és két leánya síremléke. Felirata (a szerzö olvasata): IT FEKSIK VDS IGI ARTO | IANOS HASAS LEANIAVAL | [...] MNIVAL ES HAIADON LEIANIAVAL | ANNO D(OMI)NI 1574. b) Választó Gergely leánya Barbara asszony, Ötvös Antalné síremléke. Felirata: IT FEKZYK VALAZTO | GERGOLY LEANIA | BORBARA A'ZONY | OTOVOS ANTALNE | HOLT MEG NAGBODOG | A'ZONY NAPYAN 1574. c) Bányai Ötvös János síremléke. Felirata: IT FEKZIK BANAI | OTOVOS IANOS | HOLT MEG MIN | D ZENT NAPIAN | 1574

8 Felirata: HIC TVMVLAT(VS) E(ST) LVCAS FILIVS | NOBILIS [LV]CAE LITERATI ZEOLEOSI | O FI(LI) INGENVE [---]RMI LOQVELA | MEMOR E(ST) LI(N)GVA DVLCIS AMORE TVA | AN(NO) DO(MINI) 15743 DIE OCTOBR(IS) 
Szappanos Ötvös Péter esetében például, akinek 1602-ben állított síremléke a Házsongárdi temetőből ismert - bár mára már elveszett -, az Ötvös már valódi vezetéknév, míg ő maga szappankészítő volt (HEREPEI 1988, 61-63). Nyírö Jánosról azonban a városi dokumentumok alapján tudjuk, hogy ötvösmester volt, és nem a neve által jelzett posztós mesterséggel foglalkozott (BALOGH 1985, 188; FLÓRA 2014, 412).

\section{KONKLÚZIÓ}

A városfal kövein megörökítettek tehát kézmüvesek és családtagjaik voltak, és a foglalkozásuk alapján a városi elithez tartoztak, azaz ahhoz a tehetős réteghez, akik jelentős szerepet vittek a város vezetésében is. A szabók mellett az ötvös céh bírt a legnagyobb hatalommal ilyen értelemben, mivel a Kolozsvár kör-

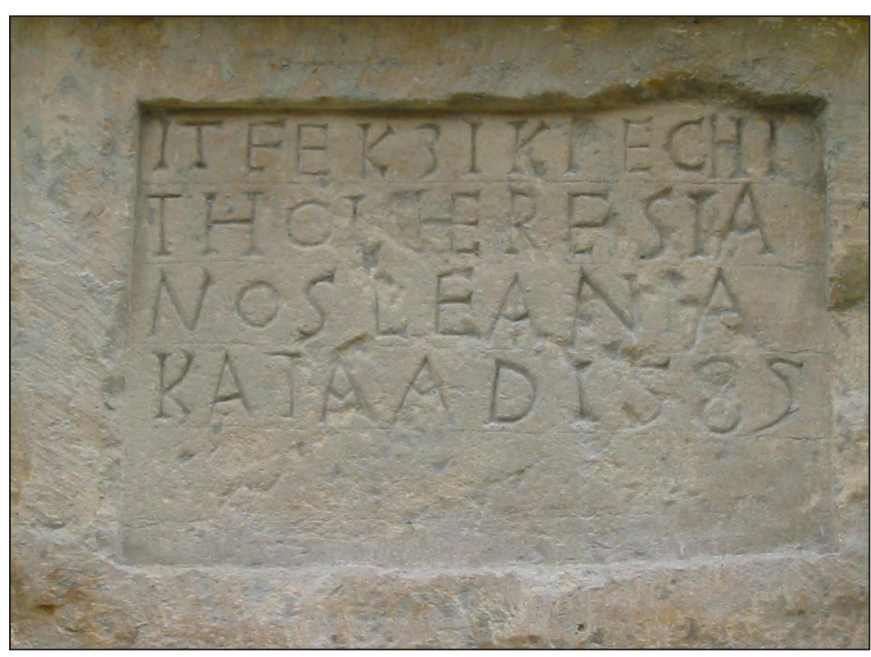

9. kép. Péchi Tölchéres János Kata nevü leányának síremléke (fotó: Mérai Dóra). Kolozsvár, városfal. Felirata: IT FEKZIK PECHI | THOLCHERES IA | NOS LEANJA | KATA A(NNO) D(OMINI) 1595 nyéki arany- és ezüstbányáknak köszönhetően jelentősen hozzájárultak a város virágzásához, és ők adták a legtöbb vezető városi tisztviselőt (FLóRA 2009; 2014, 167). Ezek a tehetős polgárok meglepően szerény módját választották az emlékállításnak. Míg a lutheránus Szebenben számos, gazdagon díszített és feliratozott síremlék tanúsítja, hogy a városi elit továbbra is ragaszkodott jogához, hogy a város főterén álló templomban temetkezzen (ALBU 2002), az abban az időszakban antitrinitárius Kolozsváron úgy tűnik, radikálisabb volt ez a váltás: csak néhány síremlék ismert templombelsőkből, és ezek is lényegesen egyszerübb kialakításúak, mint Szebenben. Ezzel párhuzamosan a városi elit temetkezései megjelentek az újonnan kialakított köztemetőkben a sírfeliratok tanúsága szerint. Ez a jelenség megfelel a nyugat-európai protestáns területeken megfigyelteknek, ahol a lutheránus városi közösségek jobban ragaszkodtak hagyományaikhoz ezen a téren, mint a radikálisabb protestáns felekezetek (ZERBE 2007).

A köztemetökben állított síremlékek, sírjelek már elhelyezésüknél fogva is egyszerübb kialakításúak, mint a templomok padozatába beillesztett sírfedlapok. Az időjárás viszontagságainak kitett kövekre nem volt érdemes finoman kidolgozott díszítést faragni, és az alkalmazott, gyenge minőségü kőanyag ezt nem is nagyon engedte. A városfal két vonulata közt kialakított köztemető azonban a presztízsreprezentáció új, egyedi formáját tette lehetővé: a városi rang egyik fontos jelképének, a városfalnak köveibe, azaz magának a városnak a „testébe” vésett megemlékező feliratok szerény kialakításuk ellenére hatásosan kommunikálták az ott eltemetettek és családjaik rangját és a város életében betöltött szerepüket. Ebben az értelemben hasonlóan határozott hangon szólnak a marosújvári és magyarzsombori templom falának kváderköveiből kialakított síremlékek is. A templom mellett egykor létezett temető sírjelei már régen eltüntek, a két felirat azonban őrzi az elhunytak emlékét, amíg csak a templom áll.

\section{KÖSZÖNETNYILVÁNÍTÁS}

A tanulmány alapját képező terepmunka a Magyar Tudományos Akadémia - Isabel és Alfred Bader müvészettörténeti kutatási támogatásának segítségével zajlott.

\section{AJÁNLOTT IRODALOM}

Balogh, J. (1944). Pákei Lajos rajzai Kolozsvár müemlékeiről. Kolozsvár: Erdélyi Múzeum-Egyesület. 
Mérai Dóra • Falba vésett emlékek. Egy 16. századi síremléktípus példái Erdélyböl

Herepei, J. (1988). A Házsongárdi temetö régi sírkövei: Adatok Kolozsvár müvelödéstörténetéhez. Budapest: Akadémiai Kiadó.

Lővei, P. (2009). Posuit hoc monumentum pro aeterna memoria: Bevezető fejezetek a középkori Magyarország síremlékeinek katalógusához (Doktori értekezés). Magyar Tudományos Akadémia, Budapest.

Mérai, D. (2019). Halál, érzelmek és család a 16-17. századi Erdélyben. A síremlékek mint az érzelmek történetének forrásai. In Erdélyi G. (szerk.), Érzelmek és mostohák-Mozaikcsaládok a régi Magyarországon (pp. 57-90). Budapest: MTA Történettudományi Intézet.

\section{IRODALOMJEGYZÉK}

Albu, I. (2002). Inschriften der Stadt Hermannstadt aus dem Mittelalter und der frühen Neuzeit. Hermannstadt: Hora Verlag - Arbeitskreis für Siebenbürgische Landeskunde Heidelberg.

Balogh, J. (1985). Kolozsvári kőfaragó mühelyek. XVI. század. Budapest: A Magyar Tudományos Akadémia Müvészettörténeti Kutató Csoportja.

Deák, F. (1879). Magyar feliratú sírkövek a XVI. századból. Archaeologiai Értesitő 13, 358-359.

Deák, F. (1886). A kolozsvári ötves legények strikeja 1573-ban és 1576-ban: székfoglaló értekezés. Budapest: Magyar Tudományos Akadémia.

Erll, A. (2011). Memory in Culture. Basingstoke: Palgrave. https://doi.org/10.1057/9780230321670

Flóra, Á. (2014). The Matter of Honour. The Leading Urban Elite in Sixteenth Century Cluj and Sibiu (Doktori disszertáció). Central European University, Department of Medieval Studies, Budapest.

Flóra, Á. (2009). Prestige at Work. Goldsmiths of Cluj/Kolozsvár in the Sixteenth and Seventeenth Centuries. Saarbrücken: Verlag Dr. Müller.

Gross, J. (1925). Die Gräber in der Kronstadter Stadtpfarrkirche. Jahrbuch des Burzenländer Sächsischen Museums 1, 132-154.

Herepei, J. (1988). A Házsongárdi temetö régi sirkövei: Adatok Kolozsvár müvelödéstörténetéhez. Budapest: Akadémiai Kiadó.

Istvánfi, Gy. (2001). Veszendö templomaink I. Erdélyi református templomok. Budapest: Nemzeti Tankönyvkiadó.

Jakab, E. (1870). Oklevéltár Kolozsvár története első kötetéhez. Buda: Magyar Királyi Egyetemi Könyvnyomda.

Jakab, E. (1888). Kolozsvár története. Második kötet oklevéltárral. Újabb kor. Nemzeti fejedelmi korszak (1540-1690). Budapest: Szabad kir. Kolozsvár város közönsége.

Jakab, A. Zs. (2012). Ez a kö tétetett...: Az emlékezet helyei Kolozsváron (1440-2012). Adattár. Kolozsvár: Kriza János Néprajzi Társaság, Nemzeti Kisebbségkutató Intézet. 
Mérai Dóra • Falba vésett emlékek. Egy 16. századi siremléktípus példái Erdélyböl

Kelemen, L. (1977). A marosvásárhelyi református temető legrégibb sírkövei. In B. Nagy M. \& Szabó T. A. (szerk.), Müvészettörténeti tanulmányok (pp. 185-190). Bukarest: Kriterion.

Kerny, T. (2002). A kolozsvári múzeum középkori kőtára. Kutatástörténeti áttekintés. Erdélyi Múzeum 3-4, 70-83.

Koslofsky, C. M. (2000). The Reformation of the Dead. Death and Ritual in Early Modern Germany, 1450-1700. New York: Palgrave. https://doi.org/10.1057/9780230286375

Kühlbrandt, E. (1927). Die evangelische Stadtpfarrkirche A.B. in Kronstadt. Kronstadt: Kirchengemeinde - Druck Honterus.

Lővei, P. (2009). Posuit hoc monumentum pro aeterna memoria: Bevezető fejezetek a középkori Magyarország síremlékeinek katalógusához (Doktori értekezés). Magyar Tudományos Akadémia, Budapest.

Lőwy, D., Demeter V., J. \& Asztalos, L. (1996). Kőbe írt Kolozsvár. Kolozsvár: Nis.

Mérai, D. (2012-2013). Funeral Monuments from the Transylvanian Principality in the Face of the Reformation. New Europe College Yearbook, 201-237.

Mihály, M. (2013). Monumente renascentiste, baroce şi neoclasice din patrimoniul Muzeului Naţional de Istorie a Transilvaniei [Reneszánsz, barokk és neoklasszikus emlékek az Erdélyi Nemzeti Történeti Múzeumból] (Doktori disszertáció). Babeş-Bolyai Tudományegyetem, Történelem és Filozófia Kar, Kolozsvár.

Nagyajtai Kovács, I. (1840). Vándorlások Kolozsvár' várfalai körül 1840-ben májusban. Nemzeti Társalkodó $6,1-46 ; 7,49-55 ; 8,57-62 ; 9,65-72 ; 10,73-76$.

Nagyajtai Kovács, I. (1843). Kolozsvári régiségek. Tudománytár 14, 67-76.

Oexle, O. G. (1982). Die Gegenwart der Toten. In H. Braet \& W. Verbeke (eds.), Death in the Middle Ages (pp. 19-77). Leuven: Leuven University Press.

Roth, H. (2006). Hermannstadt. Kleine Geschichte einer Stadt in Siebenbürgen. Cologne: Böhlau.

Szabó T., A. (szerk.) (1995). Erdélyi Magyar Szótörténeti Tár. 7. kötet. Budapest - Bukarest: Akadémiai Kiadó - Kriterion.

Zerbe, D. (2007). Memorialkunst im Wandel. Die Ausbildung eines lutherischen Typus des Grab- und Gedächtnismals im 16. Jahrhundert. In C. Jäggi \& J. Staecker (eds.), Archäologie der Reformation: Studien zu den Auswirkungen des Konfessionswechsels auf die materielle Kultur (pp. 117-163). Berlin: Walter de Gruyter. 